\title{
IDOL FRAGMENT OF THE MAKÓ-KOSIHY-ČAKA CULTURE FROM BUDAPEST-KÖÉRBEREK SITE
}

\author{
L ÁS Z L Ó R E M É N Y I
}

\begin{abstract}
The idol fragment found at the Makó-Kosihy-Čaka site excavated on the outskirts of Budapest (Kőérberek) can be classified as a cylindrical idol of the Makó-Kosihy-Čaka and Somogyvár-Vinkovci cultures. The depiction of the face and headdress of the idol from Köérberek is more elaborate compared to other idols. The headdress is similar to the headdresses observed in three graves of the Early Bronze Age cemetery in Franzhausen. Based on these, in the second half of the $3^{\text {rd }}$ millennium BC, a close connection can be established between the communities living in different areas of the Carpathian Basin.
\end{abstract}

Keywords: Hungary, Early Bronze Age, idol, headdress, diadem, Makó-Kosihy-Čaka culture.

\section{GEOGRAPHICAL AND CULTURAL ENVIRONMENT OF THE BUDAPEST- -KÖÉRBEREK SITE}

Budapest-Köérberek can be found on the south-western border of Budapest, in the Budaörs basin separating the Tétényi plateau from the Buda hills, on the southern sloping side of a hill rising north of the Hosszúréti stream (Fig. 1).

During the archaeological works at the site, an area of 26000 square meters was excavated between 2003 and 2005. During the excavation remains of several periods were discovered, including 150 pits of the Makó-Kosihy-Čaka culture settlement (Horváth et al. 2005; Horváth/Horváth/ Terei 2006; Terei 2005).

The Budaörs basin served as a significant communication route between the area lying west of the Buda hills and the Danube. We already know of several Early Bonze Age (by Hungarian terminology) settlements in the basin. A major settlement of the Makó-Kosihy-Čaka culture came to light in the source area of the Hosszúréti stream (Horváth/ Reményi/Tóth 2004; Reményi/Tóth 2004). Stray finds from the same period were unearthed on the territory of the Budaörs Airport (Kalicz-Schreiber 1994, fig. 14). A Makó-Kosihy-Caka grave was found along the former Vasvári barracks of the Köérberek-dülő (Kalicz-Schreiber 1994, fig. 14) and a settlement of the Nagyrév culture is known in Leányka street (Nagy 1971). Albertfalva (Endrödi/Reményi 2016), the largest so far excavated settlement of the Bell Beaker Csepel group, lies at the mouth of the Hosszúréti stream (Fig. 1).

\section{CULTURAL CONTEXT OF THE MAKÓ- -KOSIHY-ČAKA SITE}

The Makó-Kosihy-Čaka features in Köérberek appear on the whole territory of the excavated area, forming larger groups and settlement centres. The present state of the find material does not yet allow for more chronological statements or to attempt observing chronological differences between the individual settlement centres.

The characteristic pot of the Makó-Kosihy-Čaka culture (Fig. 2: 1) can be found in the material of the settlement (Kulcsár 2009, with many examples in Plates; Vladár 1966, fig. 14: 7; 17: 2; 31, Typ 2). The analogies of the amphora (Fig. 2: 2) can be found in the material of the Somogyvár-Vinkovci culture (Tasić 1984, pl. III: 5; IV: 7). The analogies of the small handled jug (Fig. 2: 3) is known from the grave at Budapest-Aranyhegyi út, dated to the late Makó period (Kalicz-Schreiber 1994, fig. 2: 3) and other sites of the Makó-Kosihy-Čaka culture (Kulcsár 2009, fig. 18) and from the sites of the Somogyvár-Vinkovci culture (Ecsedy 1978, pl. VIII: 1; Kulcsár 2009, fig. 48). The moustache ornament (Fig. 2: 4) is well-known in the Makó-Kosihy-Čaka culture (Kalicz 1984, pl. XXI: 2; XXII: 7) and in the 'Begleitkeramik' of the Bell Beaker Csepel group (Kalicz-Schreiber 1984, pl. XXXVI: 1). Analogies of the internally decorated bowls uncovered on the site are found among the bowls that were dated to the late Makó-Kosihy-Čaka culture (Kulcsár 1999, pl. 3; 2009, fig. 27-30) and among similar bowls of the Somogyvár-Vinkovci culture (Kulcsár 1999, pl. 4; 2009, fig. 59; 60). The so far restored and examined

\footnotetext{
1 The excavation was led by György Terei; the excavation of prehistoric features was directed by László András Horváth, Borbála Maráz and Gábor Szilas. The object presented here was found by László András Horváth. I am very grateful for the right to publish the idol.
} 


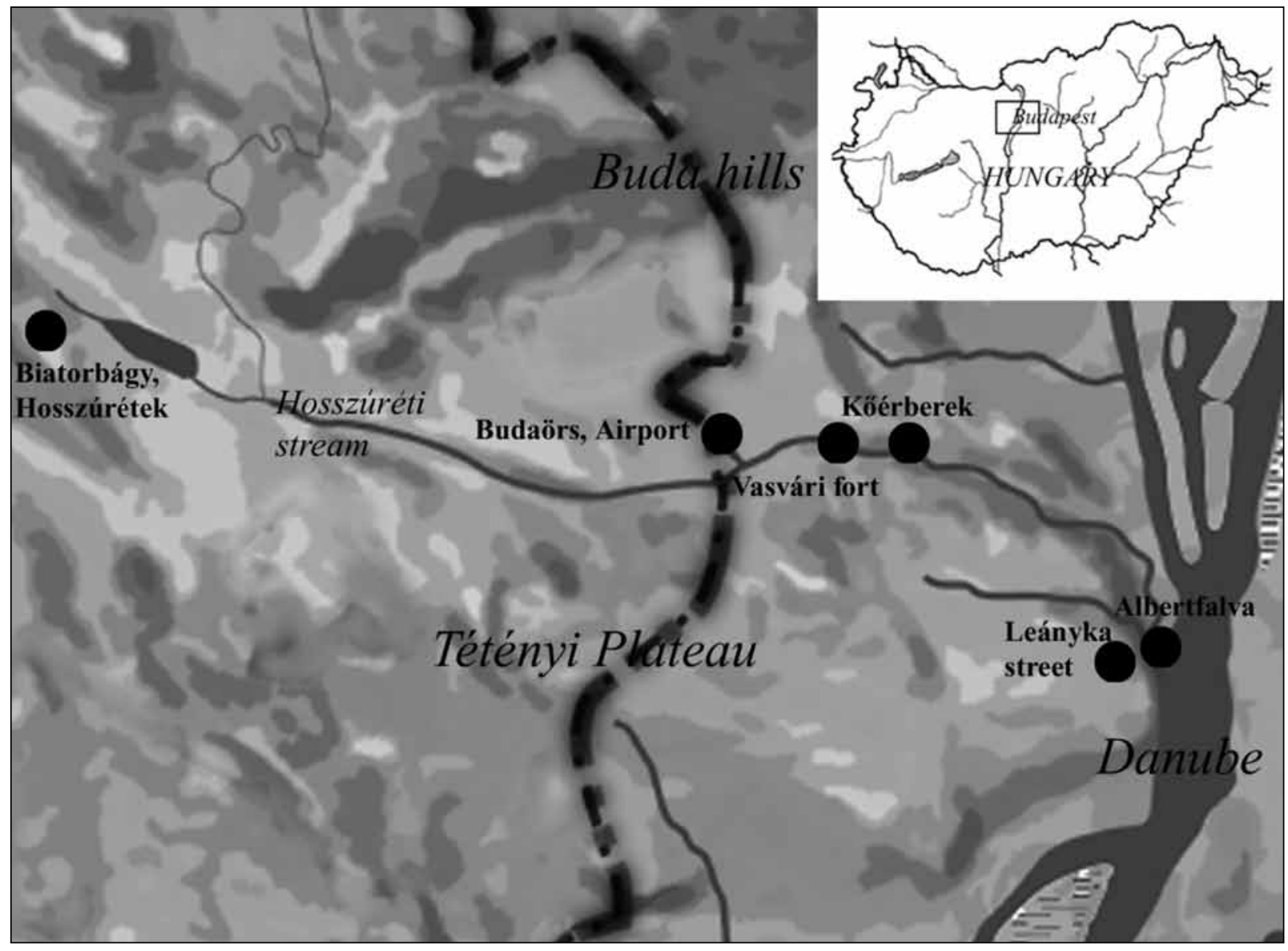

Fig. 1. The localisation of Budapest XI. district, Kőérberek site.

pottery, according to the Hungarian terminology, belongs to the phase 2 of the Early Bronze Age, which is the period of the Makó-Kosihy-Čaka culture, the Somogyvár-Vinkovci culture and the Bell-Beaker Csepel group (Bóna 1992; Kalicz-Schreiber 1984). Based on the radiocarbon dates, we can place this period between $2600 / 2500$ and 2200/2100 BC (Durman/Obelić 1989; Maran 1998, 351-354; Primas 1996, 166-168; Raczky/Hertelendi/Horváth 1992; Reményi/Endrődi 2016).

\section{ARCHAEOLOGICAL CONTEXT OF THE IDOL FRAGMENT}

The idol fragment to be presented here was found in a pit that started with a dark brown discoloration shaped as a regular circle, at a depth of twenty centimetres beneath the feature's level of appearance, in the company of Makó-Kosihy-Čaka sherds. At a depth of $45 \mathrm{~cm}$, an ashy discolouration emerged, from which a large amount of ceramics and animal bones came to light. A cone of clay was plastered to the bottom of the pit, into which a pot was placed.
Under the pot lay six larger stones, mainly querns (Fig. 3).

The analogies of the pots (Fig. 4: 1-3) are found in the Makó-Kosihy-Čaka culture (e. g. Kalicz 1984, pl. XXII: 4, 9, 12), just as the analogy of the amphora (Fig. 4: 4; e. g. Kalicz 1984, pl. XXII: 11). The analogy of the biconical vessel (Fig. 4:5) is found in the Bell Beaker Csepel group (e. g. Kalicz-Schreiber 1984, pl. XXXLV: 15) similarly to the mug (Fig. 4: 6; Kalicz-Schreiber 1984, pl. XXXII: 7; XXXV: 2-5).

\section{CULTURAL CONTEXT OF THE IDOL FRAGMENT}

The idol fragment, with a length of $6.6 \mathrm{~cm}$ and a diameter of $2.8 \mathrm{~cm}$ at its neck, is made from clay with sand tempering and is well-fired (Fig. 5). Although the body of the idol is missing, based on its rounded neck and the widening observable at the broken surface, it is not one of the flat idols widely spread in the period of the Somogyvár-Vinkovci and Makó-Kosihy-Čaka cultures (Bondár 1995, 218-220; Durman 1988, cat. 34-36; Kalicz 1984, 


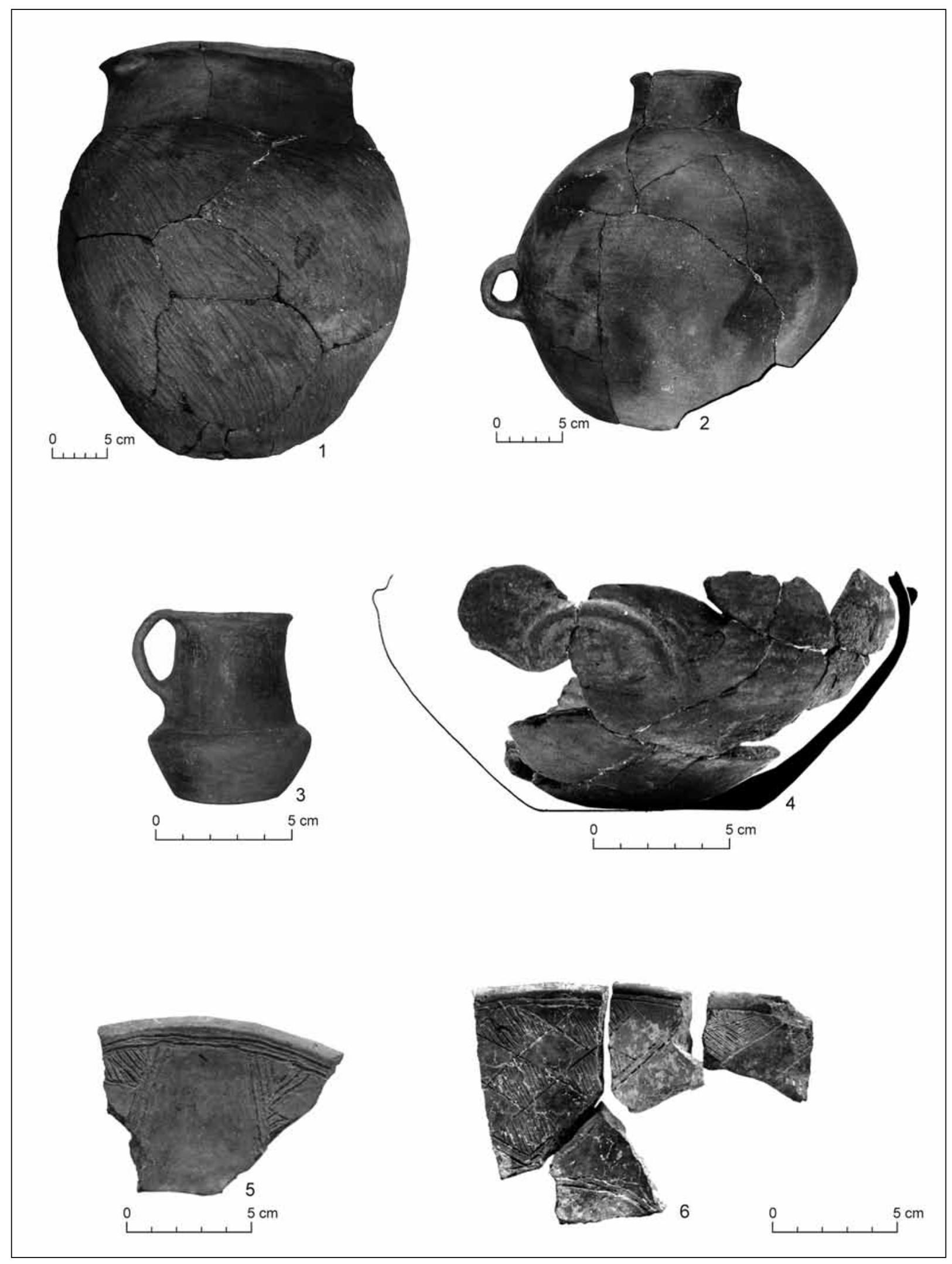

Fig. 2. Ceramic finds from Budapest-Kőérberek, Makó-Kosihy-Čaka settlement. 


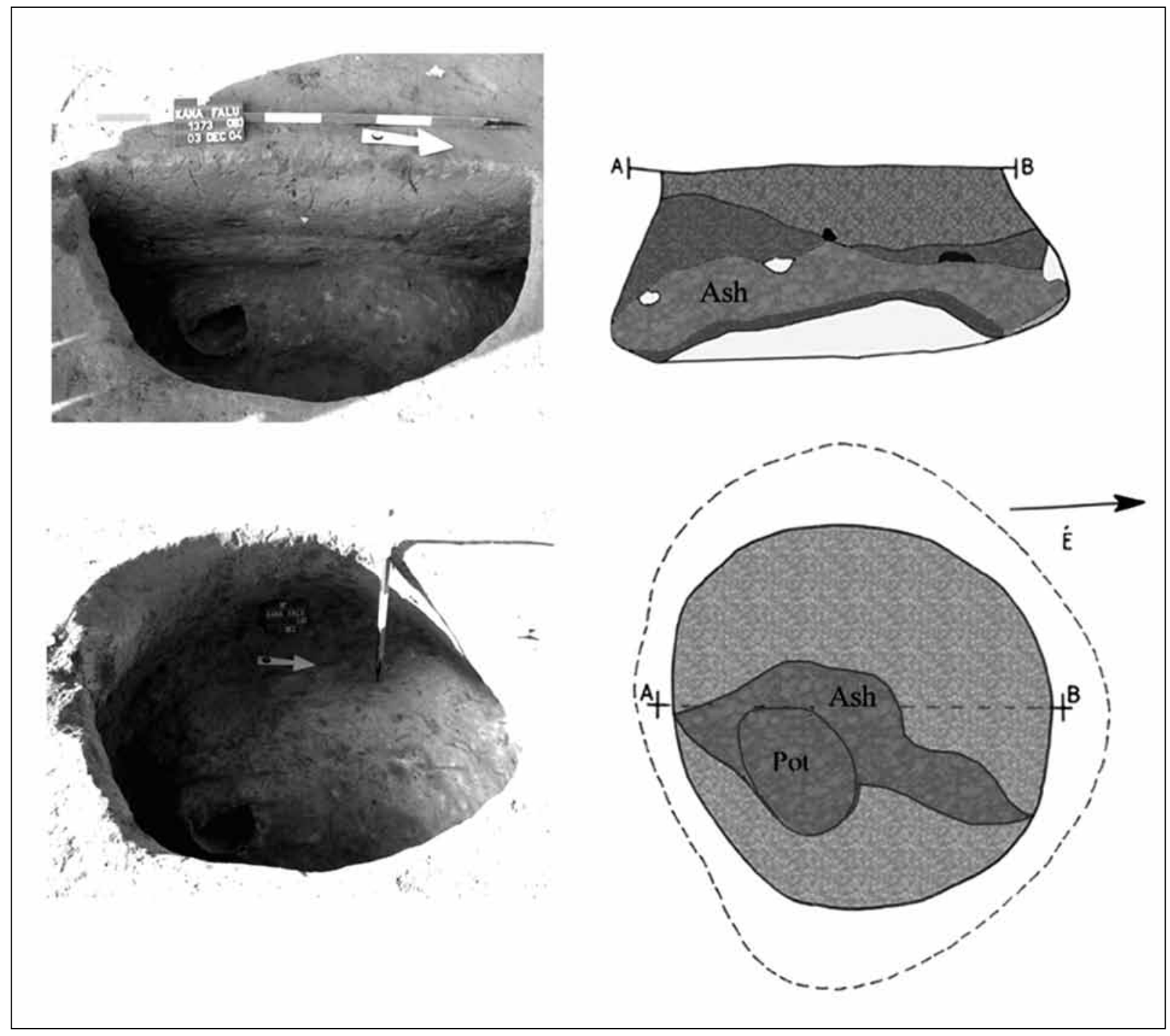

Fig. 3. The feature No. 1373 at Budapest-Köérberek site.

80, pl. X: 7). The idol from Köérberek belongs to the more rarely found idols having a cylindrical body. So far we know of one intact and four fragmented items of this type.

The closest analogies to the idol fragment from Köérberek is an idol fragment (Fig. 7: 2) from the Debrecen-Dombos-tanya site of the Makó-Kosihy-Čaka culture (Dani/Cséki 2017, 203, fig. 7), an intact idol (Fig. 7: 5) from the Börzönce-Temetői-dűlő site of the Somogyvár-Vinkovci culture (Bondár 1995, pl. 120: 1) and a head without body (Fig. 7:5) from the same (Börzönce) site (Bondár 1995, pl. 120: 2). A headless idol fragment (Fig. 7: 3) was found at Dörgicse site of the Somogyvár-Vinkovci culture (Éri 1969, 86, site 18/9, pl. 6: 3; Bondár 1995, pl. 121: 3), another headless idol fragment (Fig. 7: 4) was found at Nagygörbő-Várhegy site of the Somogyvár-Vinkovci culture (Nováki 1965, fig. 7; Bondár 1995, pl. 121: 4).
The neck of the idol form Köérberek was broken at the same place as the neck of the two headless idols and a head without body. Both the intact pieces from Börzönce and the two headless ones (Dörgicse, Nagygörbő) are probably females based on the representations of the breasts.

The faces of the idol from Köérberek and an idol from Debrecen, unlike the faces of the ones at Börzönce, are realistically elaborated: the eyes, the nose, even the nostrils are well visible. The upper part of the face of the idol from Köérberek is framed by an elongation of the plastically marked eyebrow. This motif appears on one of the anthropomorphic urns from Ozd, Center site of the late Baden culture (Kalicz 1970, pl. 69; 70) and it is similar to the eyebrow of two face-lids found at Troy III (Blegen/Caskey/Rawson 1951, pl. 61). This period is dated to the second half of the $3^{\text {rd }}$ millennium BC. The face is framed by 


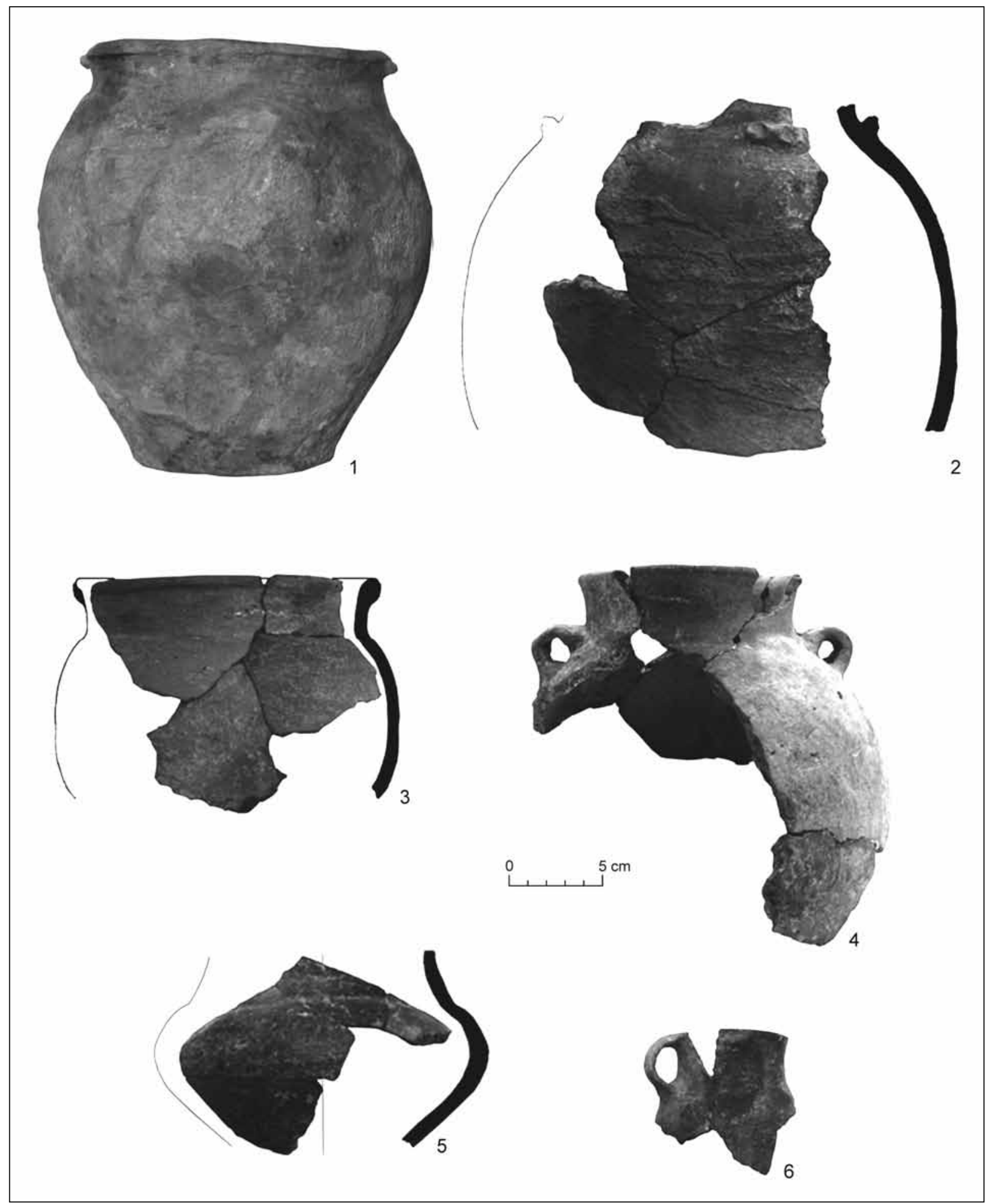

Fig. 4. The ceramic finds from the feature No. 1373 at Budapest-Kőérberek site.

a semi-circular plastically marked eyebrow on the head-fragment from Tószeg (Kovács 1973; 1977, pl. 44) and on the askos from Tiszafüred (Kovács 1973, fig. 9; 1977, pl. 45; 46; Szatmári 2003, fig. 2: 11). Both can be dated to the first half of the $2^{\text {nd }}$ millennium
BC (Raczky/Hertelendi/Horváth 1992). So the motif was generally used in the $3^{\text {rd }}$ and $2^{\text {nd }}$ millennia BC.

The elaboration of the ears is realistic as well; a hole marking the opening of the ear is surrounded by a rib pricked in a semicircle (Fig. 5). 


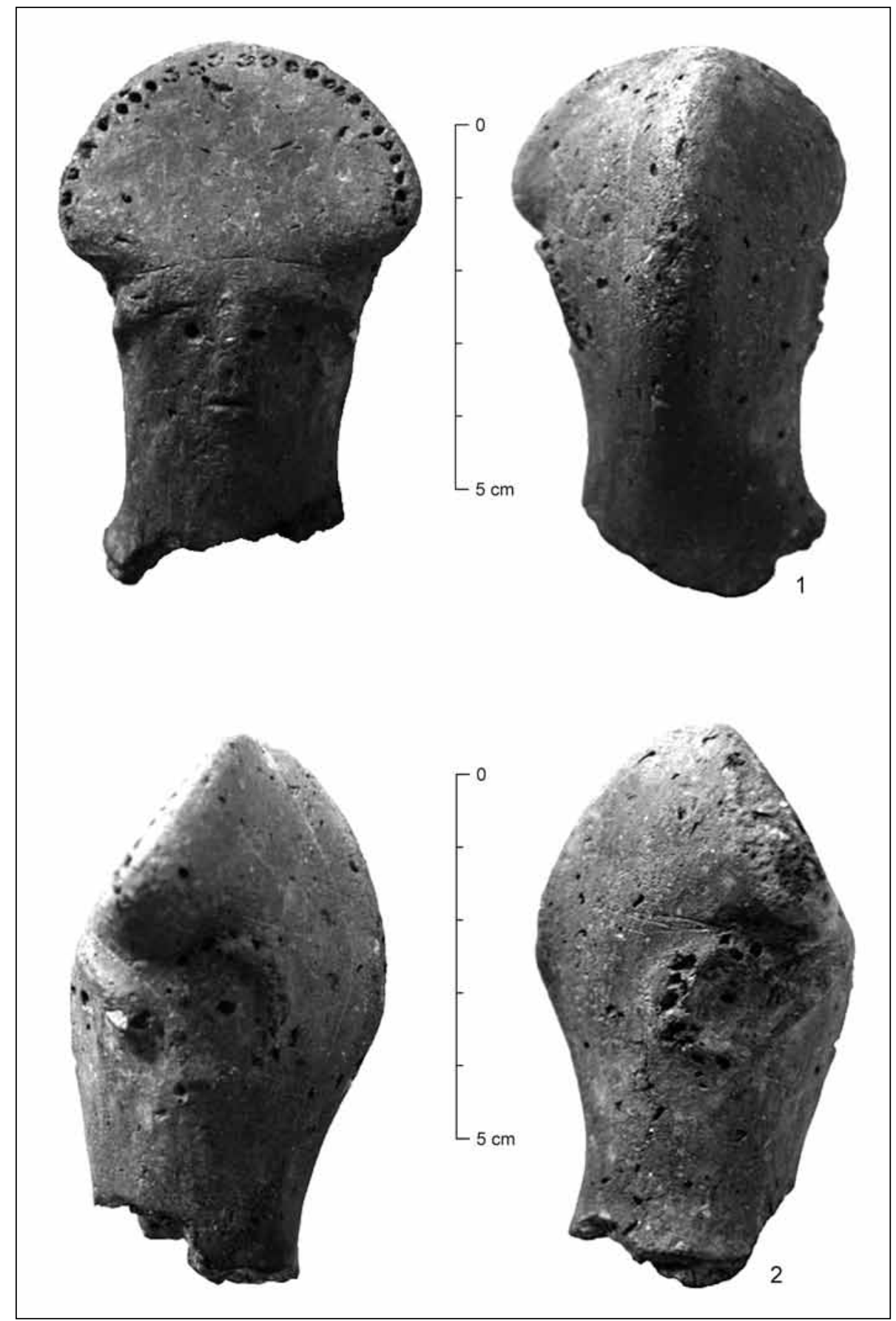

Fig. 5. The idol fragment from Budapest-Kőérberek site.

The most peculiar part of the idol fragment is the semicircular headdress. The headdress is separated from the head by a line above the eyebrows, continuing with a break behind the ears. We can interpret the line as a diadem. Concerning the wearing of the simplest headdress, the diadem, we have information from the previous age, the period of the Baden culture. In a ritual grave at Vörs-Majorság, a diadem made of copper sheets was found (Banner 1956, 111, pl. LXXXVII). This grave is interpreted as belonging to an individual with a prominent social status or a shaman (Horváth 2004, 205). On the head of the probable female idol found at Včelince (Novotná 2004, fig. 3) a double row of points marks the diadem, above which we see the representation of the hair and not a headdress similar to that of Köérberek. Tiara representations are also known from the Reinecke 
Bronze Age A and B Period (Jelínek/Valent 2019, fig. 3; 5; Topál 1973).

The headdress of the idol from Köérberek is attached to the head at an angle of about 45 degrees. In the front, the semicircular part is bordered by a ow of twenty-five pricked points (Fig. 5). There is a pronounced rib on the back of the headdress. The rib starts at the peak of the semicircle, in the back, and spans the whole head.

The head of the intact idol of Börzönce and the lone head, though in a strongly schematic manner, fashion a similar headdress with the rib. The headdress of the idol from Debrecen was broken, but the rib of the headdress is visible.
The rib either represents plaits in the hair or belongs to the ornament and holds the headdress from the back. We think that the ribs of the headdresses are important attributes of the idols from Köérberek, Börzönce and Debrecen. Similar idols with headdresses are known from the eastern part of the Balkan (Turkey, Kırklareli-Kanlıgeçit site) from a similar period (Karul 2005, fig. 3; 4), but the ribs on the headdress of these idols are missing. Based on the lack of a basic attribute, we believe that Turkish idols with headdresses are similar in form but have a different cultural background.

More complex headdresses comparable to the idols of Köérberek, Börzönce and Debrecen were

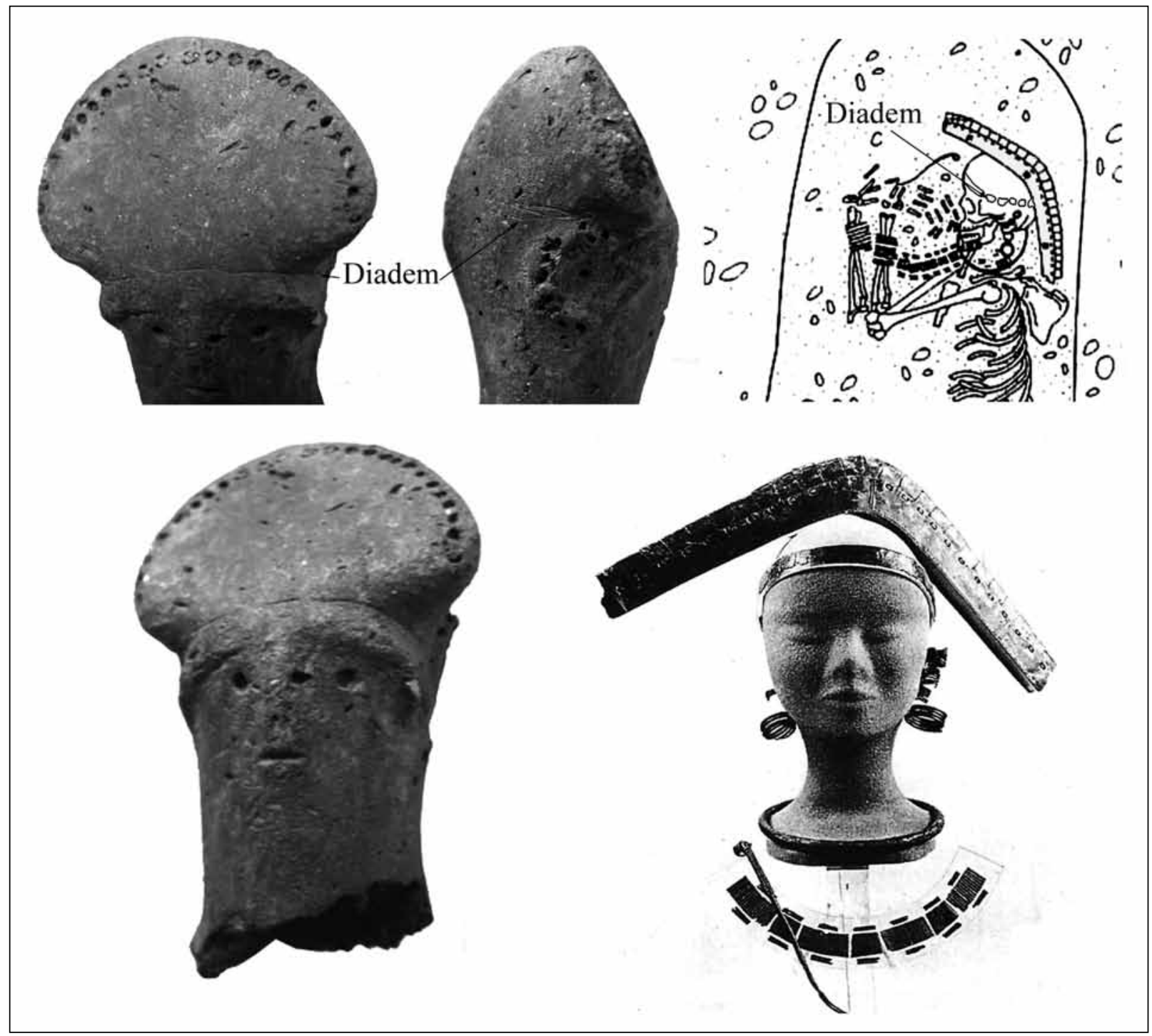

Fig. 6. The diadem on the idol and in the grave 110 at Franzhausen I (after Neugebauer/Neugebauer 1997, pl. 41). The idolhead and the reconstruction of the wearing of the headdress from grave 110 at Franzhausen I (after Neugebauer/Neugebauer 1997, pl. 640: 1) 
brought to light in three female graves of the Early Bronze Age cemetery at Franzhausen I - in grave 64 (Neugebauer/Neugebauer 1997, 88, 89, pl. 22; 440), in grave 110 (Neugebauer/Neugebauer 1997, 116, pl. 41; 450) and in grave 727 (Neugebauer/Neugebauer 1997, 422 , 423, pl. 305; 559). The headdresses were made up of two larger metal plates bent in the middle, with another smaller metal sheets bent over it. The number of the smaller sheets in graves 64 and 727 is 35 , and in grave 110 it is 25 . It is probable that the same number of sheets in these two graves is not accidental. The reason for this and the different number of the sheets in grave 110 is probable connected with social status and/or ritual phenomena.

The form of headdresses corresponds to the form and ornament of the Köérberek idol. In grave 110 at Franzhausen, a copper diadem was found on the skull, therefore it is straightforward that the line running around the forehead of the Köérberek idol can also be interpreted as a diadem (Fig. 6). At the ears of the skull in the same grave a pair of earrings were also found (Fig. 6), based on which we may consider the rows of points framing the ears of the idol to be representations of earrings too. The idol from Köérberek confirms the correct reconstruction (Neugebauer/Neugebauer 1997, pl. 640: 1) of the wearing of the headdress from grave 110 at Franzhausen.

The idol fragment from Köérberek and idol fragments from Köérberek, Börzönce, Dörgicse and Debrecen were found at the sites of the Somogyvár-Vinkovci and Makó-Kosihy-Čaka cultures. Based on radiocarbon dates, we can place this period between 2600/2500 and 2200/2100 BC (Durman/Obelic 1989; Maran 1998, 351-354; Primas 1996, 166-168; Raczky/Hertelendi/Horváth 1992). On the other hand, the graves from Franzhausen cemetery can be dated to the Reinecke Bronze Age A (Neugebauer 1994) after 2300/2200 BC (Forenbaher 1993; Harding 1980; Müller 1999). This means that this phenomenon existed for a well-defined period of time (the second half of the $3^{\text {rd }}$ millennium BC) and was spread over a larger territory.

The headdresses found at Franzhausen, especially the headdress from grave 110 and the headdress of the Köérberek idol - in addition to the immediately apparent similarities in form - correspond each other in details like the hardly visible, but clearly marked diadem on the idols, moreover the number of ornaments and the number of points pricked on the idols in the same place. Based on the headdresses it is probable that the idol of Köérberek

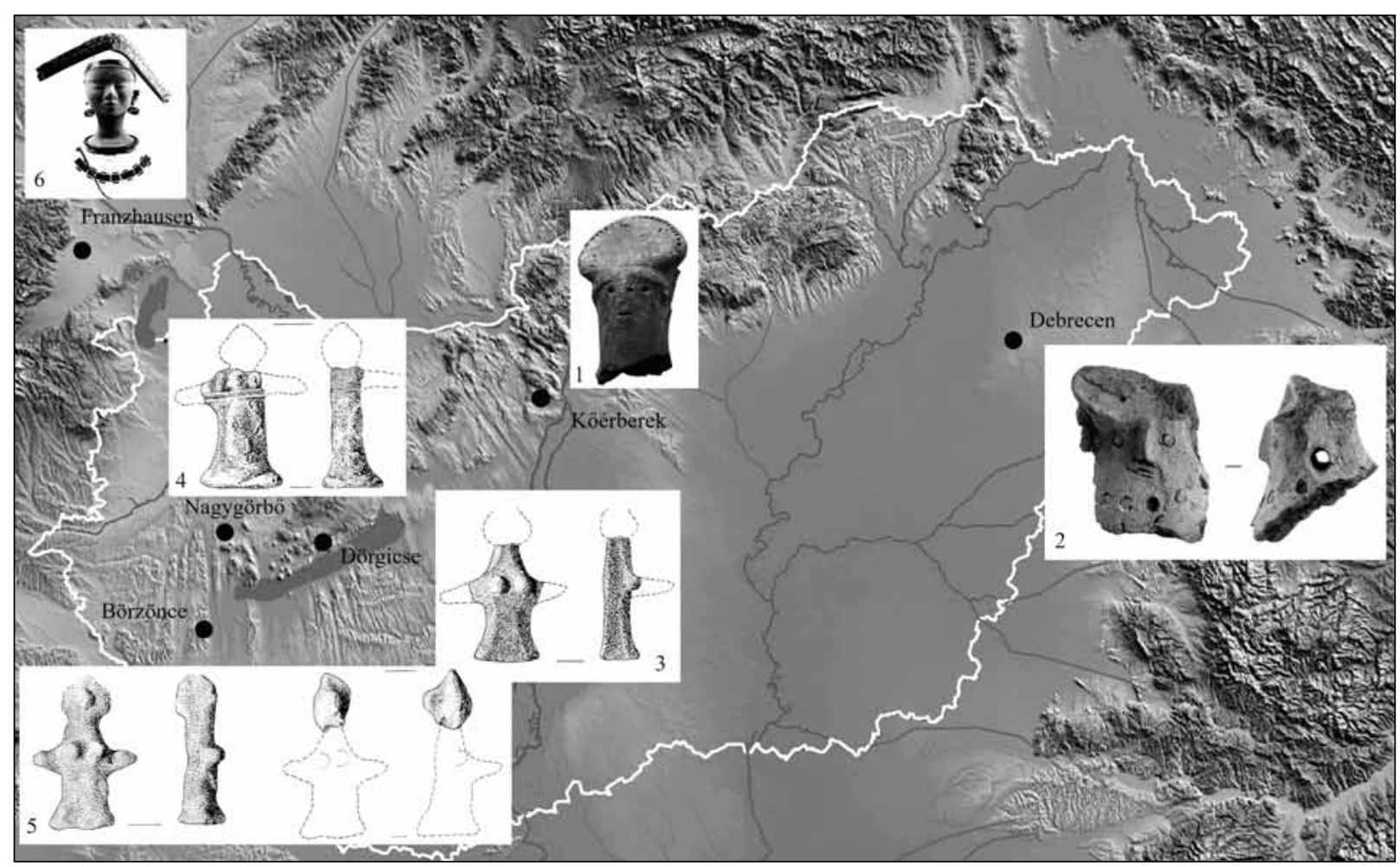

Fig. 7. Idol fragments. 1 - Budapest XI. Kőérberek; 2 - Debrecen (after Dani/Cséki 2017, 203, fig. 7); 3 - Dörgicse (after Bondár 1995, pl. 121: 3); 4 - Nagygörbő (after Bondár 1995, pl. 121: 4); 5 - Börzönce (after Bondár 1995, pl. 120: 1) and head of other idol, probably with cylindrical body (after Bondár 1995, pl. 120: 2); 6-Franzhausen I (after Neugebauer/Neugebauer 1997, pl. 640: 1). 
represented an individual with an exceptional social status, similarly to the one lying in grave 110 of Franzhausen (Neugebauer/Neugebauer 1997, 30). It can only be assumed whether women of higher status, wearing headdresses similar to the three women of Franzhausen, lived at Köérberek as well (based on analogies, the idol of Köérberek most probably had a female body as well), at the site of the Makó-Kosihy-Čaka culture, and also at the sites of the Somogyvár-Vinkovci culture (Dörgicse, Nagygörbő, Börzönce). This means, therefore, that the three communities living several hundred kilometres away from each other, had not only identical social structures, but - based on the detailed similarities between the attributes of socially outstanding individuals - we can also assume that the three communities in the western part of the Carpathian Basin possessed a common ideological background as well, manifested in the form of identical rites, beliefs and myths (Fig. 7).

The idol of Köérberek thus represented an individual with outstanding status. The broken head of the idol was found in a pit of which we can assume, even without the idol, that it is not one of the average refuse pits (Fig. 3). To the bottom of the pit, in the middle, there was a plastered cone of clay. Such phenomena are known from the period of the Middle Copper Age onwards. Researchers consider the connection of these plastered clay heaps, found in pits which are interpreted as sacrificial pits, with omphalos, known in the antiquity as representing the centre, the axis of the world. In these pits intact or deliberately broken tools (into two pieces) were frequently deposited, while a layered, ashy fill is often observable (Bánffy 1985; 1990-1991; Makkay 1981). After the clay plastering was finished in the pit of Köérberek, an intact pot and stone tools were deposited after which supposedly a fire was lit. The idol fragment was placed into the layer above the ashy one. On the basis of the previous analogies we can also interpret the pit of Kőérberek as a sacrificial pit.

Only the broken head of the idol was uncovered from the pit, its body could either have been in the upper layer of the pit that was removed with the humus, or was not placed into the pit at all. Based on the broken idol head of Börzönce and the two headless items, it is highly likely that the head of the Köérberek idol was not broken off by chance either. The beheading of the idol might have symbolized killing the person represented by the idol and burying the head in a sacrificial pit can be interpreted as a symbolic substitute for a ritual human sacrifice. Ancient historical and anthropological examples are known about the ritual murder of different leaders (chiefs, kings). In early societies, the power of the leader is accompanied by a sacred content too. In these cases the health, youth and fertility of the leader determine the fate of the community as well, the catastrophes affecting the community are explained by the illness, aging or weakening of the leader. Therefore, the leader cannot get old and after a specified age or period of reign, has to be killed (Frazer 1922, 264-283). In the vast majority of the cases (parallel to the increase of the leader's worldly status of power), the physical killing of the chief was substituted by either the appointment of a surrogate king at certain intervals (Frazer 1922, 283-289), or in other cases by the symbolic, ritual murder of the king. Supposedly the idol head found in the sacrificial pit at Köérberek can also be connected to such a rite. Based on the graves of Franzhausen and idol from Börzönce and idol-fragment from Dörgicse and Nagygörbő it is clear that the idol from Köérberek represents a woman with a prominent social status. By symbolically killing the idol of a woman with high social standing and burying it into a sacrificial pit, the inhabitants of the Makó-Kosihy-Čaka settlement of Köérberek were assumedly trying to ensure the health, fertility and prosperity of their community. In another approach, women wearing headdresses may also symbolize goddesses. Goddesses played an important role in early Indo-European cults (Jelínek/Valent 2019). Based on the Bronze Age headdress depictions, the roots of the goddess cult date back to the middle of the $3^{\text {rd }}$ millennium BC. 


\section{LITERATURE}

Bánffy 1985 - E. Bánffy: Kultikus rendeltetésű leletegyüttes a Kis-Balaton középső rézkorából. Archaeologiai Ertesító 112, 1985, 187-192.

Bánffy 1990-1991 - E. Bánffy: Cult and archaeological Context in Middle and South-East Europe in the Neolithic and the Chalcolithic. Antaeus 19-20, 1990-1991, 183-249.

Banner 1956 - J. Banner: Die Péceler Kultur. Acta Archaeologica Academiae Scientiarum Hungaricae 35. Budapest 1956.

Blegen/Caskey/Rawson 1951 - C. W. Blegen/L. Caskey/ M. Rawson: Troy. The Third, Fourth and Fifth Settlements. Vol. 2., Part 2. Cincinnati 1951.

Bóna 1992 - I. Bóna: Bronzezeitliche Tell-Kulturen in Ungarn. In: W. Meier-Arendt (Hrsg.): Bronzezeit in Ungarn. Forschungen in Tell-Siedlungen an Donau und Theiss. Frankfurt am Main 1992, 9-39.

Bondár 1995 - M. Bondár: Early Bronze Age Settlement patterns in south-west Transdanubia. Antaeus 22, 1995, 197-268.

Dani/Cséki 2017 - J. Dani/A. Cséki: Kora bronzkori müvészeti tendenciák a Felső-Tisza vidéken. In: J. Dani/ B. Kolozsi/E. Gy. Nagy/A. Priskin (szerk.): $M \Omega M O \Sigma V I I I$. Öskori müvészet - múvészet az őskorban. Öskoros Kutatók VIII. Összejövetelének konferenciakötete. Debrecen 2017, 201-232.

Durman 1988 - A. Durman (ed.): Vučedol - treće tisućljeće p. n. e. Vučedol - three thousand years B. C. Zagreb 1988.

Durman/Obelić 1989 - A. Durman/B. Obelić: Radiocarbon dating of the Vučedol culture complex. Radiocarbon 31, 1989, 1003-1009.

Ecsedy 1978 - I. Ecsedy: Die Siedlung der SomogyvárVinkovci Kultur bei Szava und einige Fragen der Frühbronzezeit in Südpannonien. Janus Pannonius Múzeum Évkönyve 23, 1978, 97-136.

Endrődi/Reményi 2016 - A. Endrődi/L. Reményi: A Bell Beaker settlement in Albertfalva, Hungary (2470-1950 BC). Budapest 2016.

Éri 1969 - I. Éri (ed.): Veszprém megye régészeti topográfiája. A veszprémi járás. Magyarország Régészeti Topográfiája 2. Budapest 1969.

Forenbaher 1993 - S. Forenbaher: Radiocarbon dates and absolute chronology of the Central European Early Bronze Age. Antiquity 67, 1993, 218-256.

Frazer 1922 - J. G. Frazer: The golden bough. A study in magic and religion. London 1922.

Harding 1980 - A. F. Harding: Radiocarbon calibration and the chronology of the European Bronze Age. Archeologické rozhledy 32, 1980, 178-186.

Horváth et al. 2005 - L. A. Horváth/A. Korom/Gy. Terei/ G. Szilas/L. Reményi: Előzetes jelentés az épülő Kőérberek Tóváros-Lakópark területén folyó régészeti feltárásról. $=$ Preliminary report on the archaeological excavation conducted parallel to the construction on the territory of the Kőérberek, Tóváros Residental District. Aquincumi Füzetek 11, 2005, 137-167.

Horváth/Horváth/Terei 2006 - L. A. Horváth/M. A. Horváth/ Gy. Terei: Előzetes jelentés az épülő Kőérberek Tóváros-Lakópark területén folyó régészeti feltárásról. $=$ Preliminary report on the archaeological excavation conducted parallel to the construction on the territory of the Köérberek, Tóváros Residental District. Aquincumi Füzetek 12, 2006, 159-165.
Horváth/Reményi/Tóth 2004 - L. A. Horváth/L. Reményi/ A. Tóth: Régészeti kutatások az M0 autóút bővítése kapcsán = Archaeological excavations preceding the widening of highway M0. Régészeti kutatások Magyarországon 2003, 2004, 27-49.

Horváth 2004 - T. Horváth: A new human representation from the Baden culture. A mask from Balatonőszöd. Acta Archaeologica Academiae Scientiarum Hungaricae 55, 2004, 179-237.

Jelínek/Valent 2019 - P. Jelínek/D. Valent: Náboženské ikonografie v staršej dobe bronzovej. Zborník SNM 113. Archeológia 29, 2019, 47-76.

Kalicz 1970 - N. Kalicz: Clay Gods. The Neolithic Period and Copper Age in Hungary. Budapest 1970.

Kalicz 1984 - N. Kalicz: Die Makó-Kultur. In: N. Tasić (Hrsg.): Kulturen der Frühbronzezeit des Karpatenbeckens und Nordbalkans. Beograd 1984, 93-107.

Kalicz-Schreiber 1984 - R. Kalicz-Schreiber: Komplex der Nagyrév-Kultur. In: N. Tasić (Hrsg.): Kulturen der Frühbronzezeit das Karpatenbeckens und Nordbalkans. Beograd 1984, 133-194.

Kalicz-Schreiber 1994 - R. Kalicz-Schreiber: Siedlungsfunde und ein Bandgrab der Frühbronzezeitlichen Makókultur in Budapest. Zalai Múzeum 5, 1994, 39-59.

Karul 2005 - N. Karul: Anatolische Idole in Osttrakien. Kırklareli-Kanlıgeçit. In: B. Horejs/R. Jung/E. Kaiser/ B. Teržan (Hrsg.): Interpretationsraum Bronzezeit. Festschrift für Bernard Hänsel. UPA 120. Bonn 2005, 117-121.

Kovács 1973 - T. Kovács: Representations of Weapons on Bronze Age Pottery. Folia Archaeologica 24, 1973, 7-31.

Kovács 1977 - T. Kovács: The Bronze Age in Hungary. Budapest 1977.

Kulcsár 1999 - G. Kulcsár: Kora bronzkori belső díszes talpas tálak a Dunántúlon. Savaria 24/3, 1998-1999 (1999), 115-139.

Kulcsár 2009 - G. Kulcsár: The Beginnings of the Bronze Age in the Carpathian Basin. The Makó-Kosihy-Čaka and the Somogyvar-Vinkovci cultures in Hungary. Varia Archaeologica Hungarica 23. Budapest 2009.

Makkay 1981 -J. Makkay: Eine Kultstätte der Bodrogkeresztúr-Kultur in Szarvas und Fragen der sakralen Hügel. Mitteilungen des Archäologischen Instituts der Ungarischen Akademie der Wisenschaften 10-11, 1980-1981, 1981, 45-57, 340-350.

Maran 1998 - J. Maran 1998: Kulturwandel auf dem griechischen Festland und den Kykladen im späten 3. Jahrtausend v. Chr. UPA 53. Bonn 1998.

Müller 1999 - J. Müller: Zur Radiokarbondatierung des Jung- bis Endneolithikums und der Frühbronzezeit im Mittelelbe-Saale-Gebiet (4100-1500 v. Chr.). Bericht der Römisch-Germanischen Kommission 80, 1999, 31-90.

Nagy 1971 - T. Nagy: Budapest XXII. Leányka út. In: Sz. A. Bürger (szerk.): Az 1970. év régészeti kutatásai. Régészeti Füzetek 1/24. Budapest 1971, 5.

Neugebauer 1994 - J.-W. Neugebauer: Die frühe und beginnende mittlere Bronzezeit in Ostösterreich südlich der Donau. Zalai Múzeum 5, 1994, 85-111.

Neugebauer/Neugebauer 1997 - Ch. Neugebauer/J.-W. Neugebauer: Franzhausen. Das frühbronzezeitliche Gräberfeld I. Fundberichte aus Österreich. Materialheft A5. Wien 1997. 
Nováki 1965 - Gy. Nováki: A Nagygörbő-Várhegy-i korabronzkori erődített telep. Archaeologiai Értesító 92, 1965, $168-175$.

Novotná 2004 - M. Novotná: Niekol'ko poznámok k antropomorfným urnám badenskej kultúry. In: J. Bátora/ L. Veliačik (Hrsg.): Einflüssse und Kontakte alteuropäischer Kulturen. Festschrift für Jozef Vladár zum 70. Geburtstag. Nitra 2004, 75-81.

Primas 1996 - M. Primas: Velika Gruda I. Hügelgraber des frühen 3. Jahrtausends v. Chr. im Adriagebeit-Velika Gruda, Mala Gruda und ihr Kontext. UPA 32. Bonn 1996.

Raczky/Hertelendi/Horváth 1992 - P. Raczky/E. Hertelendi/ F. Horváth: Zur absoluten Datierung der bronzezeitlichen Tell-Kulturen in Ungarn. In: W. Meier-Arendt (Hrsg.): Bronzezeit in Ungarn. Forschungen in Tell-Siedlungen an Donau und Theiss. Frankfurt am Main 1992, 42-47.

Reményi/Endrődi 2016 - L. Reményi/A. Endrődi: The Chronological Status of the Early Bronze Age Settlement of the Bell Beaker-Csepel Group in Albertfalva. In: A. Endrődi/L. Reményi (eds.): A Bell Beaker settlement in Albertfalva, Hungary (2470-1950 BC). Budapest 2016, 221-227. Reményi/Tóth 2004 - L. Reményi/A. Tóth: Öskori telepek, római kori árokrendszer, avar sírok Biatorbágy-
-Hosszúrétek lelöhelyen = Prehistoric settlement, a ditch system from the Roman period, Avar graves at the site of Biatorbágy-Hosszúrétek. Aquincumi Füzetek 10, 2004, 160-167.

Szathmári 2003 - I. Szathmári: Beiträge zu den Vogeldarstellungen der bronzezeitlichen Tell-Kulturen. In: E. Jerem/P. Racky (Hrsg.): Morgenrot der Kulturen. Frühe Etappen der Menschheitsgeschichte in Mittel- und Südosteuropa. Budapest 2003, 513-523.

Tasić 1984 - N. Tasić: Die Vinkovci-kultur. In: N. Tasić (Hrsg.): Kulturen der Frühbronzezeit des Karpatenbeckens und Nordbalkans. Beograd 1984, 15-32.

Terei 2005 - Gy. Terei: Előzetes jelentés a Kőérberek-Tóváros lakópark területén folyó Árpád-kori falu feltárásáról. $=$ Preliminary report on the excavation of a village from the Árpádian Period on the territory of the Köérberek-Tóváros residental district. Régészeti kutatások Magyarországon 2004, 2005, 37-72.

Topál 1973 - J. Topál: Bronzkori lemezdiadém Ócsáról. Studia Comitatensia 2, 1973, 3-11.

Vladár 1966 - J. Vladár: Zur Problematik der Kosihy-Čaka-Gruppe in der Slowakei. Slovenská archeológia 14, 1966, 245-336.

László Reményi

Castle Headquartes Integrated Regional Development Centre Nonprofit Private Limited Company

Daróczi utca 3

H - 1113 Budapest

laszlo.remenyi73@gmail.com

\title{
Fragment idolu kultúry Makó-Kosihy-Čaka z Budapešti-Kőérbereku
}

\author{
László Re ményi
}

\section{SÚHRN}

Fragment idolu z lokality kultúry Makó-Kosihy-Čaka preskúmanej na periférii Budapešti (poloha Kőérberek) je možné priradit valcovitému typu idolov kultúr Makó-Kosihy-Caka a Somogyvár-Vinkovci.

Zobrazenie tváre a pokrývky hlavy fragmentu idolu z Kőérberku je v porovnaní s inými idolmi prepracovanejšie a jeho najzvláštnejšou častou je polkruhovitá pokrývka hlavy, ktorá je k hlave idolu pripevnená v približne 45-stupňovom uhle. Vpredu je polkruhovitá čast’ pokrývky hlavy idolu ohraničená radom 25 drobných vpichov a na jej zadnej strane sa nachádza výrazné rebro, ktoré začína na vrchole polkruhu a pokrýva celú hlavu idolu. Podobné rebrá sa vyskytli aj na d’alších idoloch z Börzönce a Debrecínu, preto sa domnievame, že rebrá na pokrývkach hlavy idolov sú ich dôležitými atribútmi. Podobné pokrývky hlavy ako na predmetných idoloch pochádzajú zo ženských hrobov
64, 110 a 727 na pohrebisku zo staršej doby bronzovej vo Franzhausene. Idoly z Kőérberku, Börzönce a Debrecínu patria do druhej polovice 3. tisícročia pred n. 1 .

Na základe hrobov z Franzhausenu, idolu z Börzönce a fragmentov idolov z Dörgicse a Nagygörbő je zrejmé, že idol z Kőérberku zobrazuje ženu s významným sociálnym statusom.

Obyvatelia sídliska kultúry Makó-Kosihy-Čaka v Köérberku sa symbolickým zabitím idolu zobrazujúceho ženu s vysokým sociálnym statusom a jeho uložením do obetnej jamy snažili svojej komunite zabezpečit zdravie, plodnost’ a prosperitu. Nie je vylúčené, že ženy nosiace podobnú polkruhovitú pokrývky hlavy symbolizovali bohyne. Bohyne hrali dôležitú úlohu vo včasných indoeurópskych kultoch. Na základe zobrazení pokrývok hlavy z doby bronzovej sa korene kultu bohýň datujú do polovice 3. tisícročia pred n. 1 . 
